\title{
Consumption of Cooked Common Beans or Saponins Could Reduce the Risk of Diabetic Complications
}

This article was published in the following Dove Press journal: Diabetes, Metabolic Syndrome and Obesity: Targets and Therapy

\author{
David Calderón Guzmán' \\ Hugo Juárez Olguín (iD) 2,3 \\ Quetzalli Veloz Corona ${ }^{2}$ \\ Maribel Ortiz Herrera ${ }^{4}$ \\ Norma Osnaya Brizuela' \\ Gerardo Barragán Mejía (iD ${ }^{4}$ \\ 'Laboratory of Neurosciences, Instituto \\ Nacional de Pediatría (INP), Mexico City, \\ Mexico; ${ }^{2}$ Laboratory of Pharmacology, \\ INP, Mexico City, Mexico; ${ }^{3}$ Department \\ of Pharmacology, Faculty of Medicine, \\ Universidad Nacional Autónoma de \\ México, Mexico City, Mexico; \\ ${ }^{4}$ Laboratory of Experimental \\ Bacteriology, INP, Mexico City, Mexico
}

\begin{abstract}
Several risks for diseases, such as atherosclerosis, renal diseases, and diabetes, have inextricably been linked with obesity. Nowadays, this health-risk-laden disease is being managed with assorted types of drugs, some of which guarantee modest benefits. The chronic inflammatory effect of obesity has a negative effect in insulin signaling, a situation attributable to insulin resistance that culminates in high blood sugar inputs seen in diseases such as type 2 diabetes and metabolic syndrome. Food such as beans with different bioactive compounds could reduce the risk of diabetic complications. Demand for bean products is growing because of its robust contents of several health-promoting components, eg, saponins. Saponins are characterized by containing lower glucose and cholesterol levels and have been doted with antioxidant activities, as well as anti-inflammatory and anti-diabetic effects. In this writing, the attributes of saponins in providing substantial health and nutritional benefits in humans, as well as in improving and ameliorating diabetic complications, were reviewed.
\end{abstract}

Keywords: beans, saponins, diabetes

\section{Introduction}

The health implications of obesity lie in triggering the risk of atherosclerosis, renal diseases, vesicular lithiasis, and diabetes. Diabetes mellitus (DM) is a complex metabolic disease, epidemically global with expected toll of 380 million patients by 2025 . $^{1}$ In particular, type 2 diabetes mellitus (T2DM), due to generalized unhealthy lifestyles, has reached epidemic proportions in the last few decades. ${ }^{2}$ Unfortunately, diabetic retinopathy is one of the secondary complications encountered by the patients suffering from chronic diabetes mellitus. The two major characteristic features of diabetic retinopathy are macular edema and angiogenesis. The properties of endostatin, a valuable substance employed in the treatment of cancer can be exploited as a potential antiangiogenic therapy agent. ${ }^{3}$ In addition, diabetes is an important health load of obesity. Most patients with this disease require insulin for its control, with its consequent hypoglycemic effects that characterize a crucial point in the struggle for the containment of the pathology. ${ }^{4}$ Currently, there are various types of drugs used for the management of obesity that guarantee modest benefits. Insulin resistance is a major risk factor for diseases such as T2DM and metabolic syndrome. Several clinical studies have shown that leguminous plants such as dried beans are able to reduce insulin resistance and other related T2DM parameters due to their antioxidant activities. ${ }^{5}$
Correspondence: Hugo Juárez Olguín Nacional de Pediatría, Avenida Imán $\mathrm{N}^{\circ} \mathrm{I}$, 3rd Piso Colonia Cuicuilco CP, Mexico City 04530 Mexico

$\mathrm{Tel} / \mathrm{Fax}+525556161489$

Email juarezol@yahoo.com
Diabetes, Metabolic Syndrome and Obesity: Targets and Therapy 2020:13 348I-3486

3481

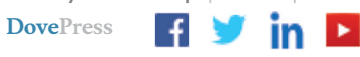

htpet/doi.org $10.214710 \mathrm{~ms} 0.5270$ 


\section{Carbohydrates and Diabetes}

Food consumption with different bioactive compounds could reduce the risk of diabetic complications. Carbohydrates are an umbrella term that encompasses sugar, fruits, vegetables, fibers, and legumes. These substances act as an energy source, and help in the control of blood glucose and insulin metabolism. Besides, they are linked with cholesterol and triglyceride metabolism, and fermentation. Carbohydrates are one of the three macronutrients in the human diet, along with protein and fat. These molecules contain carbon, hydrogen, and oxygen atoms. In addition, they play an important role in the human body. Upon consumption, their breakdown into glucose is the sole responsibility of the digestive tract and this breakdown product is the source of energy for biological and physical activities. ${ }^{6}$

\section{Saponins: Effects and Properties}

Demand for bean products is growing because of their abundant content of several health-promoting components such as saponins, found in great amount in edible bean products. Saponins are naturally occurring compounds that are widely distributed in all cells of legume plants. ${ }^{7}$ They contain a carbohydrate moiety attached to a triterpenoid or steroids. Moreover, they have been associated with upliftment of the immune system to protect the human body against cancers, and with lowering the glucose and cholesterol levels. Some saponins form an insoluble complex with cholesterol which prevents its absorption from the small intestine. ${ }^{8}$ Others cause an increase in the fecal excretion of bile acids, an indirect route for elimination of cholesterol. ${ }^{9}$ In general, the saponins are potential natural activators of AMPK; thus, a promising compound with the potential to serve as an antidiabetic substance. ${ }^{10}$

\section{Legumes and Blood Glucose Levels}

The association of legumes with low-glucose blood level is progressively being recognized. A 4-week treatment with a cooked bean supplemented (10\%) diet, Flor de Mayo bean (FMB), was found to lower blood glucose levels, due to its ability to augment blood insulin levels; decrease urine albumin and urea levels; and increase creatinine clearance. ${ }^{11}$ Beans (Phaseolus vulgaris L.) are common legumes, consumed worldwide. The wild beans contain more protein $(25.5 \%$ vs. $21.7 \%)$, ash (5.15 vs. $4.15 \%)$ and crude fiber (7.08\% vs. $5.04 \%)$ compared to cultivated beans. Also, they contain less fat ( 0.56 vs. $0.89 \%$ ) and carbohydrates (61.64 vs. $68.05 \%$ ). Sulfur amino acids were found to be limiting in both groups of beans, as expected; however, the cultivated beans had a higher content of the limiting amino acids. $^{12}$

\section{Green Vegetable Soya Beans}

There are five triterpenoid saponins with different chemical structures (Table 1). ${ }^{13}$ Saponins owe their name to the characteristic of forming foam. They are compounds that are found in various plants. Saponins come from the Saponaria plant that has formerly been used to form soap (sapon $=$ soap) ${ }^{14}$ In their chemical structure, they are glycosides with a polycyclic aglycone called sapogenin. The aglycone is the free part of a glucoside. It can be in the form of a steroid or a triterpenoid choline bound through C3. ${ }^{15}$ Triterpenes can be subdivided into 20 different groups with particular chemical structures in each of them. The aglycone part is covalently attached to one or more glycones (sugar) and this can be glucose, galactose, glucuronic acid, or xylose. ${ }^{16}$ There are reports that highlight the biological activities of saponins. For example, the sea cucumber Holothuria thomasi saponin is reported to have a hypoglycemic effect in diabetic rats, ${ }^{17}$ by stimulating insulin secretion and regeneration of beta cells of the pancreas. Moreover, for its chemical structure and antioxidant properties, it activates responsible enzymes to use glucose. It is important to

Table I Triterpenoid Saponins and Their Chemical Structures

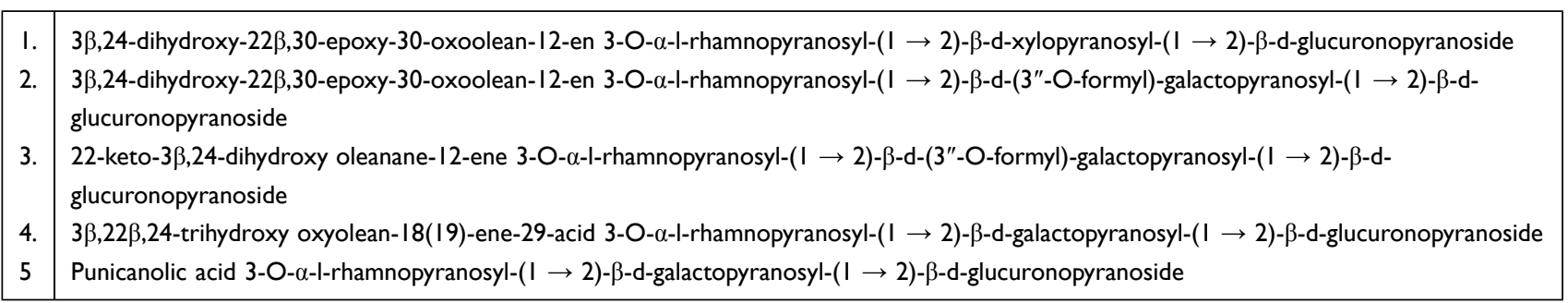


know the structure of saponins, because such knowledge can be used in making synthetic modifications of the substances through the insertion of functional groups that strengthen its activity or improve its affinity with the specific receptors (Figure 1). Some substances possess moderate anti-inflammatory activities. The bean hulls possess the most abundant phytochemical elements. The whole grain is a potent antioxidant with anti-inflammatory and anti-diabetic effects. ${ }^{18} \mathrm{~A}$ study with 50 grams of available carbohydrate in a meal based on black beans and rice was performed in healthy adult women ( $\mathrm{n}=12,18-65$ years). The meals were served in the mornings in different times and days for a minimum of 7 days. Blood samples were collected at time 0 (fasting), and at 30,60, 90, and 120 minutes postprandial, and were subsequently analyzed for glucose and insulin concentrations. Glucose response based on the incremental area under the curve showed a significant difference by treatment $(P=0.027)$. Changes in blood glucose concentrations were significantly different for the meals based on black bean in comparison to rice alone at 60 minutes ( $P=0.026$ and $P=0.024), 90$ minutes $(P=0.001$ and $P=0.012)$ and 120 minutes post prandial $(P=0.024$; black bean meal). This provides evidence that black bean improves glycemic response; and thus, its traditional inclusion in our daily food consumption is a promising indication for dietary guidance to reduce

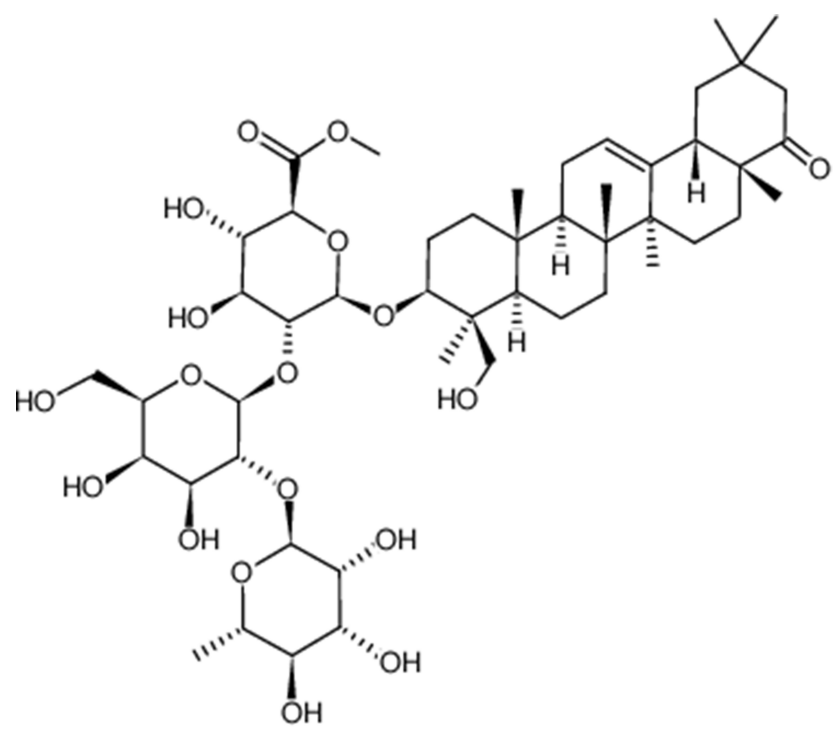

Figure I Base chemical structure of saponin. postprandial glucose and related health risks. ${ }^{19}$ Blank bean seed coat is a rich source of natural compounds such as primary saponins and flavonoids. ${ }^{20}$ Quercetin 3-O-glucoside and soya saponin Af, the principal contents of the coat, are respectively the sources of primary flavonoid and saponin. Their extracts significantly reduce the expression of SREBP1c, FAS, and HMGCR; and stimulate the expression of the reverse cholesterol transporters ABCG5/ABCG8 and CYP7A1 in the liver. In addition, they increase the expression of hepatic PPAR- $\alpha$ and consequently decrease hepatic lipid depots and promote a significant increase in bile acid secretion. ${ }^{21}$ Flavonoids and saponins from common beans have been widely studied due to their bioactivity. These studies reported that total phenolic content and antioxidant capacity of the extracts were higher when obtained from seed coats, and that flavonoids and saponins were more related with hepatic and colon cancers. $^{22}$ These authors suggest that one-day germinated black beans could increase the concentration of saponins and non-glycosylated flavonoid in sprouts and seed coats.

\section{Natural Products and Metabolic Actions}

Tecoma stans has the potential for $\alpha$-glucosidase inhibition and may provide an effective natural product to treat hyperglycemia and prevent subsequent diabetic complications. ${ }^{23}$ Many of the natural products that have a direct or indirect effect on diabetic pathways as enzyme inhibitors are saponins (Table 2). The mechanisms associated with these effects pivot around their inhibitory action on intestinal alpha-glucosidase and alpha-amylase, lens aldose reductase, advanced glycation end-products formation, postprandial hyperglycemia, and aldose reductase. In addition, saponins can provide protection against oxidative stress, and lower the levels of plasma glucose and skeletal hexokinase, as well as alter the enzyme activity of hexokinases and glucose-6-phosphate. They have positive effects on the synthesis and release insulin, including the stimulation of GLUT4 , and decrease of G6P activity. ${ }^{33}$ Likewise, they modulate the expression of enzymes involved in lipid metabolism, including peroxisome proliferator-activated receptor $\alpha$ (PPAR- $\alpha$ ), sterol regulatory element-binding protein 1 (SREBP-1), fatty acid synthase (FAS), and stearoyl CoA desaturase-1 (SCD-1) mRNA in liver. ${ }^{34}$ 
Table 2 Saponins in Natural Products That Have a Direct or Indirect Effect on Diabetes Pathways

\begin{tabular}{|c|c|c|c|}
\hline Type of Saponin & Tissue & Effect & Ref \\
\hline $\begin{array}{l}\text { Panax notoginseng } \\
\text { saponins }\end{array}$ & Skeletal myoblast cell line & $\begin{array}{l}\text { Increased insulin-induced glucose uptake, reduced blood glucose and } \\
\text { serum insulin levels, and improved glucose tolerance }\end{array}$ & [24] \\
\hline $\begin{array}{l}\text { Saponins of Momordica } \\
\text { charantia }\end{array}$ & Type 2 diabetic mice & $\begin{array}{l}\text { Restored the body weight, reduced fasting blood glucose levels, } \\
\text { ameliorated insulin resistance, and increased the proportion of hepatic } \\
\text { phosphorylated adenosine monophosphate-activated protein kinase ( } \mathrm{p} \text { - } \\
\text { AMPK)/total protein }\end{array}$ & [25] \\
\hline $\begin{array}{l}\text { Saponins of Stauntonia } \\
\text { chinensis }\end{array}$ & Type 2 diabetic $\mathrm{db} / \mathrm{db}$ mice & $\begin{array}{l}\text { Exhibited hypoglycemic activities and modulated hyperlipidemia that was } \\
\text { associated with type } 2 \text { diabetes }\end{array}$ & [26] \\
\hline $\begin{array}{l}\text { Saponins of } \\
\text { Boussingaultia gracilis }\end{array}$ & Three-week old male mice & $\begin{array}{l}\text { Reduced the hepatic damage underlying steatosis, modulated lipid } \\
\text { metabolism, enhanced adipocyte thermogenesis, restored insulin sensitivity } \\
\text { and glucose homeostasis, and alleviated inflammation status }\end{array}$ & [27] \\
\hline $\begin{array}{l}\text { Saponins of } \\
\text { Catharanthus roseus }\end{array}$ & $\begin{array}{l}\text { Streptozotocin-induced diabetic } \\
\text { mice }\end{array}$ & $\begin{array}{l}\text { Had a hypoglycemic effect that may be explained by an increase in insulin } \\
\text { secretion }\end{array}$ & [28] \\
\hline $\begin{array}{l}\text { Panax noto ginseng } \\
\text { saponins }\end{array}$ & $\begin{array}{l}\text { Subunits of NF- } \mathrm{KB} p 50 \text { and } \mathrm{p} 65 \\
\text { from macrophages in culture } \\
\text { medium }\end{array}$ & $\begin{array}{l}\text { Anti-inflammatory properties, inhibition of platelet aggregation, } \\
\text { improvement of blood flow and insulin resistance }\end{array}$ & [29] \\
\hline $\begin{array}{l}\text { Saponin from sea } \\
\text { cucumber }\end{array}$ & $\begin{array}{l}\text { C57BL/6 mice fed with a high fat } \\
\text { diet }\end{array}$ & $\begin{array}{l}\text { Inhibited lipid synthesis and accelerated lipid } \beta \text {-oxidation and glycolysis in } \\
\text { the liver }\end{array}$ & [30] \\
\hline $\begin{array}{l}\text { Balanites aegyptiaca } \\
\text { Del. (Zygophyllaceae) } \\
\text { fruits }\end{array}$ & $\begin{array}{l}\text { Streptozotocin-induced diabetic } \\
\text { male albino Wistar rats }\end{array}$ & Reduced the fasting plasma glucose level and total cholesterol & [31] \\
\hline $\begin{array}{l}\text { Saponin Extracts from } \\
\text { Dianthus basuticus }\end{array}$ & $\begin{array}{l}\alpha \text {-amylase and } \alpha \text {-glucosidase } \\
\text { inhibitory activities in vitro }\end{array}$ & $\begin{array}{l}\text { Exhibited a competitive mode of inhibition on } \alpha \text {-amylase and promising } \\
\text { antidiabetic and antioxidant activity }\end{array}$ & [32] \\
\hline
\end{tabular}

\section{Conclusion}

Indeed, control of blood glucose, plasma cholesterol, and nutrient absorption through dietary saponins could provide substantial health and nutritional benefits in humans, as well as reduce diabetic complications.

\section{Acknowledgments}

We thank Dr. Cyril Ndidi Nwoye Nnamezie, an expert translator whose native language is English, for his help in preparing this manuscript. Besides, we thank Instituto Nacional de Pediatria for the support received through Federal Resources to publish this article.

\section{Author Contributions}

All authors made a significant contribution to the work reported, either in the conception, study design, execution, acquisition of data, analysis and interpretation or in all these areas. In addition, they took part either in drafting, revising, or critically reviewing the article, and gave their final approval of the version to be published; as well as agreed on the journal to which the article has been submitted; and accepted to be accountable for all aspects of the work.

\section{Funding}

This report did not receive any kind of funding.

\section{Disclosure}

The authors declare that they have no conflicts of interest for this work.

\section{References}

1. Cicero AFG, Landolfo M, Ventura F, Borghi C. Current pharmacotherapeutic options for primary dyslipidemia in adults. Expert Opin Pharmacother. 2019;20(10):1277-1288. doi:10.1080/14656566.2019. 1604687

2. Raveendran AV, Chacko EC, Pappachan JM. Non-pharmacological treatment options in the management of diabetes mellitus. Eur Endocrinol. 2018;14(2):31-39. doi:10.17925/EE.2018.14.2.31 
3. Tapan B, Anita K. Possible role of endostatin in the antiangiogenic therapy of diabetic retinopathy. Life Sci. 2015;135:131-137. doi:10.1016/j.lfs.2015.06.017

4. Hussain A, Latiwesh OB, Ali F, Younis MYG, Alammari JA. Effects of body mass index, glycemic control, and hypoglycemic drugs on serum uric acid levels in type 2 diabetic patients. Cureus. 2018;10(8): e3158.

5. Clark JL, Taylor CG, Zahradka P. Rebelling against the (insulin) resistance: a review of the proposed insulin-sensitizing actions of soybeans, chickpeas, and their bioactive compounds. Nutrients. 2018;10(4):434. doi:10.3390/nu10040434

6. Holesh JE, Martin A. Physiology, Carbohydrates, Stat Pearls [Internet]. Treasure Island (FL): Stat Pearls Publishing; 2019:1.

7. Shi J, Arunasalam K, Yeung D, Kakuda Y, Mittal G, Jiang Y. Saponins from edible legumes: chemistry, processing, and health benefits. J Med Food. 2004;7(1):67-78. doi:10.1089/109662004 322984734

8. Sidhu GS, Oakenfull DG. A mechanism for the hypocholesterolaemic activity of saponins. Br J Nutr. 1986;55(3):643-649. doi:10.1079/ BJN19860070

9. Xie Q, Gu X, Chen J, et al. Soya saponins reduce inflammation and improve serum lipid profiles and glucose homeostasis in high fat dietinduced obese mice. Mol Nutr Food Res. 2018;62(19):e1800205. doi: $10.1002 / \mathrm{mnfr} .201800205$

10. Francini F, Schinella GR, Ríos JL. Activation of ampk by medicinal plants and natural products: its role in type 2 diabetes mellitus. Mini Rev Med Chem. 2019;19(11):880-901. doi:10.2174/138955751966 6181128120726

11. Lomas-Soria C, Pérez-Ramírez IF, Caballero-Pérez J, et al. Cooked common beans (Phaseolus vulgaris L.) modulate renal genes in streptozotocin-induced diabetic rats. J Nutr Biochem. 2015;26 (7):761-768. doi:10.1016/j.jnutbio.2015.02.006

12. Sotelo A, Sousa H, Sánchez M. Comparative study of the chemical composition of wild and cultivated beans (Phaseolus vulgaris). Plant Foods Hum Nutr. 1995;47(2):93-100. doi:10.1007/BF01089257

13. Lan X, Deng K, Zhao J, et al. New triterpenoid saponins from green vegetable soya beans and their anti-inflammatory activities. J Agric Food Chem. 2017;65(50):11065-11072. doi:10.1021/acs.jafc.7b04 134

14. Singh S, Farswan M, Ali S, et al. Antidiabetic potential of triterpenoid saponin isolated from Primula denticulate. Pharm Biol. 2014;52 (6):750-755. doi:10.3109/13880209.2013.869759

15. Kareru PG, Keriko JM, Gachanja AN, Kenji GM. Direct detection of triterpenoid saponins in medicinal plants. Afr J Tradit Complement Altern Med. 2008;5(1):56-60. doi:10.4314/ajtcam.v5i1.31257

16. Sanjay S, Mamta F, Sadat A, et al. Antidiabetic potential of triterpenoid saponin isolated from Primula denticulate. Pharmac Biol. 2014;52(6):750-755. doi:10.3109/13880209.2013.86975

17. Barky AR, Hussein SA, Alm-Eldeen AA, et al. Anti-diabetic activity of Holothuria thomasi saponin. Biomed Pharmacother. 2016;84:1472-1487. doi:10.1016/j.biopha.2016.10.002

18. Luo J, Cai W, Wu T, Xu B. Phytochemical distribution in hull and cotyledon of adzuki bean (Vigna angularis L.) and mung bean (Vigna radiate L.), and their contribution to antioxidant, anti-inflammatory and anti-diabetic activities. Food Chem. 2016;201:350-360. doi:10.1016/j.foodchem.2016.01.101

19. Winham DM, Hutchins AM, Thompson SV. Glycemic response to black beans and chickpeas as part of a rice meal: a randomized crossover trial. Nutrients. 2017;9(10):10. doi:10.3390/nu9101095
20. Kumar S, Verma AK, Das M, Jain SK, Dwivedi PD. Clinical complications of kidney bean (Phaseolus vulgaris L.) consumption. Nutrition. 2013;29(6):821-827. doi:10.1016/j.nut.2012.11.010

21. Chavez-Santoscoy RA, Gutierrez-Uribe JA, Granados O, et al. Flavonoids and saponins extracted from black bean (Phaseolus vulgaris L.) seed coats modulate lipid metabolism and biliary cholesterol secretion in C57BL/6 mice. Br J Nutr. 2014;112(6):886-899. doi: $10.1017 / \mathrm{S} 0007114514001536$

22. Guajardo-Flores D, Serna-Saldívar SO, Gutiérrez-Uribe JA Evaluation of the antioxidant and antiproliferative activities of extracted saponins and flavonols from germinated black beans (Phaseolus vulgaris L.). Food Chem. 2013;141(2):1497-1503. doi:10.1016/j.foodchem.2013.04.010

23. Amit G, Tapan B. Proposed mechanism of tecoma stans in diabetesassociated complications. Nat Prod J. 2020;10:1. doi:10.2174/ 2210315510666191224114311

24. Guo X, Sun W, Luo G, et al. Panax notoginseng saponins alleviate skeletal muscle insulin resistance by regulating the IRS1-PI3K-AKT signaling pathway and GLUT4 expression. FEBS Open Bio. 2019;9 (5):1008-1019. doi:10.1002/2211-5463.12635

25. Wang Q, Wu X, Shi F, Liu Y. Comparison of antidiabetic effects of saponins and polysaccharides from Momordica charantia L. in STZinduced type 2 diabetic mice. Biomed Pharmacother. 2019;109:744750. doi:10.1016/j.biopha.2018.09.098

26. Xu J, Wang S, Feng T, Chen Y, Yang G. Hypoglycemic and hypolipidemic effects of total saponins from Stauntonia chinensis in diabetic db/db mice. J Cell Mol Med. 2018;22(12):6026-6038. doi:10.1111/ jcmm.13876

27. Liu L, Wang N, Ma Y, Liu Y, Wen D. Saponins from Boussingaultia gracilis prevent obesity and related metabolic impairments in dietinduced obese mice. Food Funct. 2018;9(11):5660-5673. doi:10.1039/C8FO01264D

28. Espejel-Nava JA, Vega-Avila E, Alarcon-Aguilar F, et al. A phenolic fraction from catharanthus roseus L. stems decreases glycemia and stimulates insulin secretion. Evid Based Complement Alternat Med. 2018;2018:7191035.

29. Zhao Y, Zheng J, Yu Y, Wang L. Panax notoginseng saponins regulate macrophage polarization under hyperglycemic condition via NF- $\kappa$ B signaling pathway. Biomed Res Int. 2018;30:9239354.

30. Meng J, Hu X, Zhang T, et al. Saponin from sea cucumber exhibited more significant effects than ginsenoside on ameliorating high fat diet-induced obesity in C57BL/6 mice. Medchemcomm. 2018;9 (4):725-734. doi:10.1039/C7MD00653E

31. Ezzat SM, Abdel Motaal A, El Awdan SAW. In vitro and in vivo antidiabetic potential of extracts and a furostanol saponin from Balanites aegyptiaca. Pharm Biol. 2017;55(1):1931-1936. doi:10. 1080/13880209.2017.1343358

32. Nafiu MO, Ashafa AOT. Antioxidant and inhibitory effects of saponin extracts from dianthus basuticus burtt davy on key enzymes implicated in type 2 diabetes in vitro. Pharmacogn Mag. 2017;13 (52):576-582. doi:10.4103/pm.pm_583_16

33. Alam F, Shafique Z, Amjad ST, Bin Asad MHH. Enzymes inhibitors from natural sources with antidiabetic activity: a review. Phytother Res. 2019;33(1):41-54. doi:10.1002/ptr.6211

34. Liu C, Shen YJ, Tu QB, et al. Pedunculoside, a novel triterpene saponin extracted from Ilex rotunda, ameliorates high-fat diet induced hyperlipidemia in rats. Biomed Pharmacother. 2018;101:608-616. doi:10.1016/j.biopha.2018.02.131 


\section{Publish your work in this journal}

Diabetes, Metabolic Syndrome and Obesity: Targets and Therapy is an international, peer-reviewed open-access journal committed to the rapid publication of the latest laboratory and clinical findings in the fields of diabetes, metabolic syndrome and obesity research. Original research, review, case reports, hypothesis formation, expert opinion and commentaries are all considered for publication. The manuscript management system is completely online and includes a very quick and fair peer-review system, which is all easy to use. Visit http://www.dovepress.com/testimonials.php to read real quotes from published authors.

Submit your manuscript here: https://www.dovepress.com/diabetes-metabolic-syndrome-and-obesity-targets-and-therapy-journal 